\title{
CHALLENGE OF DEVELOPING QUALITY PROFILE OF HIGHER EDUCATION IN UKRAINE
}

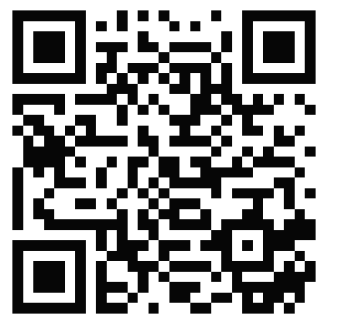

To cite this article:

\author{
Volodymyr Lugovyi, Dr. Sc., Prof. \\ First Vice-President, \\ National Academy of Educational Sciences of Ukraine \\ Kyiv, Ukraine \\ Luhovyi@ukr.net \\ https://orcid.org/0000-0003-1650-066X \\ Olena Slyusarenko, Dr. Sc., Senior Researcher \\ Vice-Director for Research, \\ Institute of Higher Education, \\ National Academy of Educational Sciences of Ukraine, \\ Kyiv, Ukraine \\ Slyusarenko_o@ukr.net \\ https://orcid.org/0000-0001-7957-1794
}

Zhanna Talanova, Dr. Sc., Senior Researcher, Assoc. Prof.

Chief Scientific Officer

Institute of Higher Education,

National Academy of Educational Sciences of Ukraine,

Analytical Manage, National Erasmus+ Office in Ukraine

Kyiv, Ukraine

zhanna_t@ukr.net

https://orcid.org/0000-0003-4007-2677

Lugovyi, V., Slyusarenko, O. \& Talanova, Zh. (2020). Challenge of developing quality profile of higher education in Ukraine.

Education: Modern Discourses, 3, 57-77.

https://doi.org/10.37472/2617-3107-2020-3-06

\begin{abstract}
In the article the challenge of developing a quality profile of the national higher education is analysed, the causes of the problem occurrence and prospects for its solution are clarified. The problem is considered, primarily, in the aspect of finding out the best university practices both as a whole, and on subject areas that is important for competitive development. It is argued that in 1990-2019 the Ukrainian higher education grew quantitatively and chaotically with a simultaneous loss of competitive quality. As a result, the country has a fragmented and dispersed, over-duplicated, profile-inadequate, institutionally and resource-weak, researchpoor, and ultimately insufficiently capable to carry out its mission network of higher education institutions. Therefore, according to the ARWU rating, Ukraine is identified as a white spot in Europe, which does not fall into the list of 60 countries in the general version and 90 countries in the sectoral (subject) version of this rating. This situation is largely due to the lack of a system of mechanisms for monitoring and evaluation, assurence and improvement the quality of higher education. In contrast to the best practices of progressive countries, Ukraine does not have developed classification, framework, association, and rating mechanisms. Accreditation mechanisms do not
\end{abstract}


cope and in principle cannot cope with the systematic diagnosis and effective motivation of the quality of higher education in the entire range of quality - from the minimum threshold to the breakthrough most perfect. To form a benchmark and justify the way out of the crisis, the best world achievements are considered in detail, Ukraine and USA are compared. Based on the case of the standard Harvard University the determination of the profile of a university quality is illustrated. The definition of the category "higher education quality profile" is given.

Key words: accreditation; association; classification; competitiveness; development; higher education; quality profile; rating; Ukraine; USA.

\section{INTRODUCTION. PROBLEM STATEMENT}

The emergence in 2003 and 2004 and the subsequent rapid global spread and recognition of the international rankings Academic Ranking of World Universities (ARWU) (Academic Ranking ..., 2020) and THE (Times Higher Education) World University Rankings (THE ..., 2020), and later since 2010 QS World University Rankings (QS ..., 2020) significantly supplemented the system of mechanisms for monitoring and evaluating the higher education quality by the global component (University Quality ..., 2015; Lugovyi \& Talanova (eds.), 2019, 2019a; Lugovyi, Slyusarenko \& Talanova, 2018, 2019; Rankings ..., 2019). Prior to that, such a system contained mechanisms (accreditation, association, classification), which, together with the later framework, are regionally and nationally and level limited, so do not give a holistic view of the true diverse quality of higher education. This is especially true of the higher level of quality at which global competition is taking place as a driver of development. After all, the quality is heterogeneous, has a wide range of perfection: from the lower mass (minimum sufficient) to the highest elite (maximum perfection) (Lugovyi \& Talanova (eds.), 2019, 2019a; Lugovyi, Slyusarenko \& Talanova, 2018, 2019; Lugovyi, 2020). The solution to the challenge of developing a higher education quality profile has become essentially and practically real with the advent of sectoral (academic subjects) ratings, especially ARWU (since 2017) as the most objective, transparent, and clear. From now on, it is possible to validly and reliably characterize (which is the most difficult) the top quality of universities (and countries), which are included in the general and sectoral versions, first of all, ARWU. The presence in 2020 in the general version of this rating of 60 countries, and in the sectoral version - 90 countries testifies to its successful empirical testing and wide applicability. Ukraine is not included in the list of these countries. So, the problem is not in ARWU, but in the quality of the Ukrainian universities (Academic Ranking ..., 2020; Shanghai Ranking's ..., 2020).

Indeed, a number of author's publications (Lugovyi \& Talanova (eds.), 2019; Lugovyi, Slyusarenko \& Talanova, 2019a; Slyusarenko, 2015; Talanova, 2010) show that the network of higher education institutions (HEIs) has changed extremely chaotically during the long period of Ukraine's independence (Fig. 1).

For example, in 1994 alone, 73 universities, academies, and institutes of higher education were opened against the background of a 9\% annual decline of the country's GDP. In 2014, 48 HEIs ceased to exist mostly due to the temporary loss of the Ukrainian territories (see Fig. 1). At the same time, the characteristics of higher education have not been improved; in particular, institutions have become even smaller on average. Since then, the number of institutions has increased again, exacerbating fragmentation and segregation, excessive duplication, profile inadequacy, institutional and resource weaknesses, research poverty, and ultimately the mission failure of the network of higher education institutions. Due to the lack of a system of mechanisms for monitoring and evaluating the quality of higher education and the impossibility of diagnosing it and creating a profile of the quality of national 
higher education, the Ukrainian society does not know the actual state and extent of the real quality crisis of higher education. Thus, the problem of creating a system of mechanisms for monitoring and evaluating the quality of higher education is relevant. It allows determining the quality profile of the national higher education, given the best world experience, primarily of the USA as a leader in higher education. In turn, an adequate response to such a challenge creates a solid basis for justifying and adopting an effective strategy for further development of higher education in Ukraine (Lugovyi \& Talanova (eds.), 2019, 2019a; Lugovyi, Slyusarenko \& Talanova, 2018, 2019; Lugovyi, Orzhel, Slyusarenko \& Talanova, 2018; Lugovyi, 2020; Prezydent Ukrainy ..., 2020).

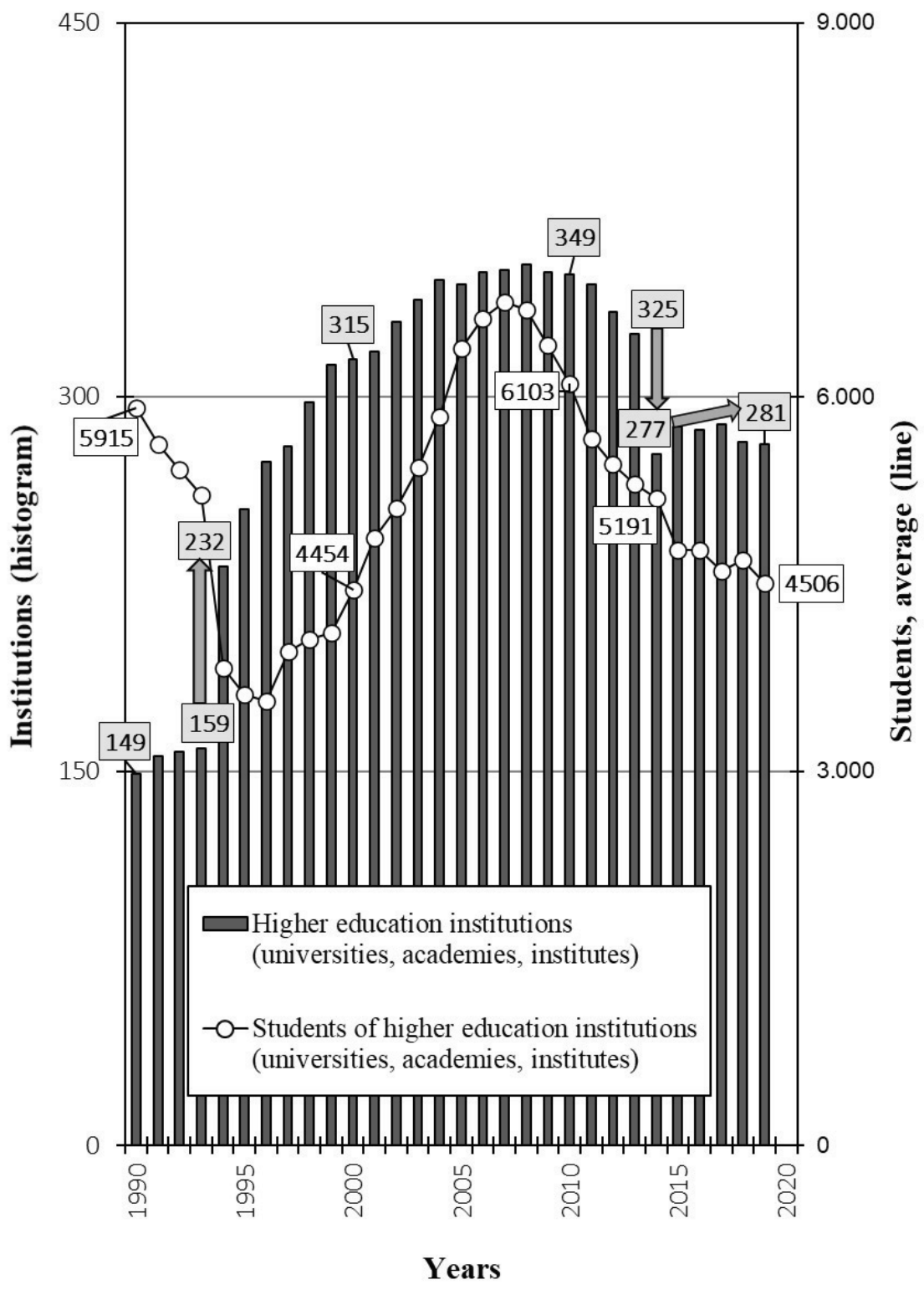

Fig. 1.

Change of the network of higher education institutions in Ukraine in 1990-2019

Source: Compiled by the authors based on: Derzhstat Ukrainy, 2020; Lugovyi \& Talanova (eds.), 2019. 


\section{LITERATURE REVIEW}

In the article both the author's research on the systematic consideration of the stated problem (Lugovyi \& Talanova (eds.), 2019, 2019a; Lugovyi, Slyusarenko \& Talanova, 2018, 2019, 2019a, 2019b; Lugovyi, 2020), and other new publications are used, i.e. Organization for Economic Co-operation and Development (OECD), World Bank, EU, National Science Foundation (NSF), international rankings ARWU, THE, QS, IREG (OECD, 2009, 2020, 2020a; Review ..., 2019; University Quality ..., 2015; Table 20 .., 2020; Gibbons, 2020; Academic Ranking ..., 2020; Shanghai Ranking's ..., 2020; THE .., 2019, 2020; QS ..., 2019, 2020; IREG ..., 2020). Also, it is used data, published in 2020 by the State Statistics Service of Ukraine, "Osvita.UA", all initiative, but not officially recognized, rating mechanisms in Ukraine, etc (Derzhstat Ukrainy, 2020; Kilkist zaiav ..., 2020; Konsolidovanyi reitynh ..., 2020; Naibilshyi bal ..., 2020; Naibilshyi bal ..., 2020a; Nikulina, Kshevetskyi \& Tereshchuk, 2019; Reitynhy VNZ, 2020; Reitynh ..., 2020; Reitynh ..., 2020a).

For Ukrainian-language and English-language queries, the Google search engine does not find the term "higher education quality profile" in scientific and practical use, except for recent author's publications. At the same time, the term "quality profile", for some other activities, is present in the information space. First of all, the search engine offers a quality model developed by Japanese researcher N. Kano (the so-called "Kano Model") and widespread in the world. The model is based on the consumer's psychological perception of product quality and has general character (Kano model, 2020; The Complete Guide ..., 2019; Vymohy ..., 2018; What is ..., 2020).

It is important that the model contains qualitative characteristics considering the product functionality of three levels - basic ("must-be", or basic functionality), performance (good functionality), attractive (best functionality). Basic features are necessary, threshold, entrance for market presence in general. Performance attributes characterize the product in terms of functional excellence for a particular class. The optimized for them ratio of quality (productivity) / price determines the competitiveness of the product in the market. Attractive features are special exciting innovative properties of the product that unforeseen, but significantly increase its functionality and attractiveness. The level distribution of qualitative characteristics is not constant over time. An attribute will drift over time from attractive to performance and then to basic (Kano model, 2020; The Complete Guide ..., 2019; Vymohy ..., 2018).

In the context of the Kano Model, the formation of competitiveness and attractiveness of the European Higher Education Area (EHEA) according to the well-known Bologna Process means the following.

First. Basic qualitative characteristics of both HEIs as a whole and individual educational programmes and the corresponding qualifications / degrees provided are not enough for the formation of the declared EHEA. The basic attributes are sufficient to ensure an integral and coherent EHEA, in particular using the Framework for Qualifications (FQ) of the EHEA and the National Qualifications Frameworks (NQFs). The basic characteristics availability is ensured by the institutional mechanism and program accreditation, which is important for enhancing the comparability, compatibility and coheritability of higher education in Europe, the recognition of degrees and qualifications in this area (University Quality ..., 2015; Lugovyi, Slyusarenko \& Talanova, 2019).

Second. Implementing the competitiveness requirement of EHEA requires some perfection of HEIs and programs. As accreditation becomes insufficient, it needs to be complemented by other monitoring and evaluation mechanisms, and at the same time by the mechanisms of motivation of higher education quality assurance and enhancement. Among them are the 
European University Association (EUA) and the European Association of Institutions in Higher Education (EURASHE) (University Quality ..., 2015; Lugovyi, Slyusarenko \& Talanova, 2019; Lugovyi \& Talanova (eds.), 2019, 2019a).

Third. Achieving attractiveness requires the usage of mechanisms to identify and motivate innovative educational activities of the highest excellence. Such the highest perfection is clarified by framework, elite association and especially rating mechanisms. In the latter (as opposed to threshold accreditation), the quality is counted from the highest university achievement. The second advantage of the rating is its global capabilities, unlike all other mechanisms (University Quality ..., 2015; Lugovyi, Slyusarenko \& Talanova, 2018, 2019; Lugovyi \& Talanova (eds.), 2019, 2019a).

Qualitative category of attractiveness is applicable to the ratings themselves. Back to 2011, the authors substantiated that among the global university rankings ARWU, THE, QS, and Webometrics (Ranking Web of Universities, Webometrics) (Ranking Web ..., 2020), the most attractive is ARWU as the most objective, transparent and clear, mission-adequate. This is confirmed by the current global spread, recognition and use of ARWU. After all, the quality problem of higher education becomes clear given the compliance of university activities with the declared university mission (Lugovyi, Slyusarenko \& Talanova, 2011, 2018, 2019; Lugovyi \& Talanova (eds.), 2019, 2019a, Slyusarenko, 2015). Relying on ARWU, China and France in 2020 made a significant qualitative leap in increasing the competitiveness and attractiveness of their universities. In particular, the universities of these two countries for the first time in history were included in the group of top 30 ARWU, which also includes institutions from the USA, UK, Switzerland, Canada, and Japan. The French Paris-Saclay University was ahead of Princeton University in mathematics for the first time, and Chinese universities took first place in 10 of the 22 academic subjects of engineering (Academic Ranking ..., 2020; Shanghai Ranking's ..., 2020).

The ratings themselves, as attractive mechanisms for determining the university quality in view of their unsurpassed opportunities and prospects, have been actively analyzed for more than 10 years by the OECD, World Bank, EU and other organizations (OECD, 2009; Review ..., 2019; University Quality ..., 2015; IREG .., 2020). In 2018, the Ukrainian government also paid attention to international ratings (Pro zatverdzhennia ..., 2018). However, the legal regulation of the use of rating mechanisms in Ukraine is essentially limited (Lugovyi, Slyusarenko \& Talanova, 2018, 2019; Lugovyi \& Talanova (eds.), 2019, 2019a).

In general, the experience of rating of HEIs, mostly proactive, has been gaining momentum in Ukraine since 2006, but has proved to be extremely unsuccessful, distrustful, and ultimately not used in public administration decisions. Some of the domestic ratings ("Compass", "National rating system for the assessment of HEIs activity") ceased to exist (Kompas ..., 2019; Pro zatverdzhennia ..., 2011), others (“Top-200 Ukraine”, Scopus, "Budget EIT $^{1}$ Score", "Contract EIT ${ }^{2}$ Score", "Consolidated Rating", and ranking of national HEIs) due to subjectivity, low validity, low probability, rather mislead society, citizens, employers, applicants than serve as a source of reliable information about the higher education systemic quality (Reitynh ..., 2020a; Reitynh ..., 2020; Naibilshyi bal ..., 2020; Naibilshyi bal ..., 2020a; Reitynhy VNZ, 2020; Konsolidovanyi reitynh ..., 2020; Nikulina, Kshevetskyi \& Tereshchuk, 2019).

This does not allow to reliably identify the positions of institutions in accordance with the university mission and its key components in the innovative type context of progress. In such conditions, each institution is oriented and orients others to profitable rating achievements. This development is facilitated by the clogging of the rating ecosystem with clearly inadequate

\footnotetext{
${ }^{1}$ External Independent Test (ukr. 3HO).
}

${ }^{2}$ External Independent Test (ukr. 3HO). 
ratings, the number of which exceeded two dozen and continues to grow. That is, the problem of ranking ratings has become more acute, as the mechanism of their simple accreditation (for example, by IREG) due to its a priori limitations does not work. An example is the Ukrainian rating "Top-200 Ukraine", which is accredited by IREG, but is biased, invalid and unbelievable and does not inspire confidence (Lugovyi, Slyusarenko \& Talanova, 2019; Lugovyi \& Talanova (eds.), 2019, 2019a; Reitynh ..., 2020a).

Summarizing the world, European and domestic experience in the development of mechanisms for monitoring and evaluation and motivation of higher education quality assurance and enhancement, the authors of this article proposed a systematic classification of such mechanisms (see Fig. 2). This system of mechanisms is well coordinated with the Kano Model by levels.

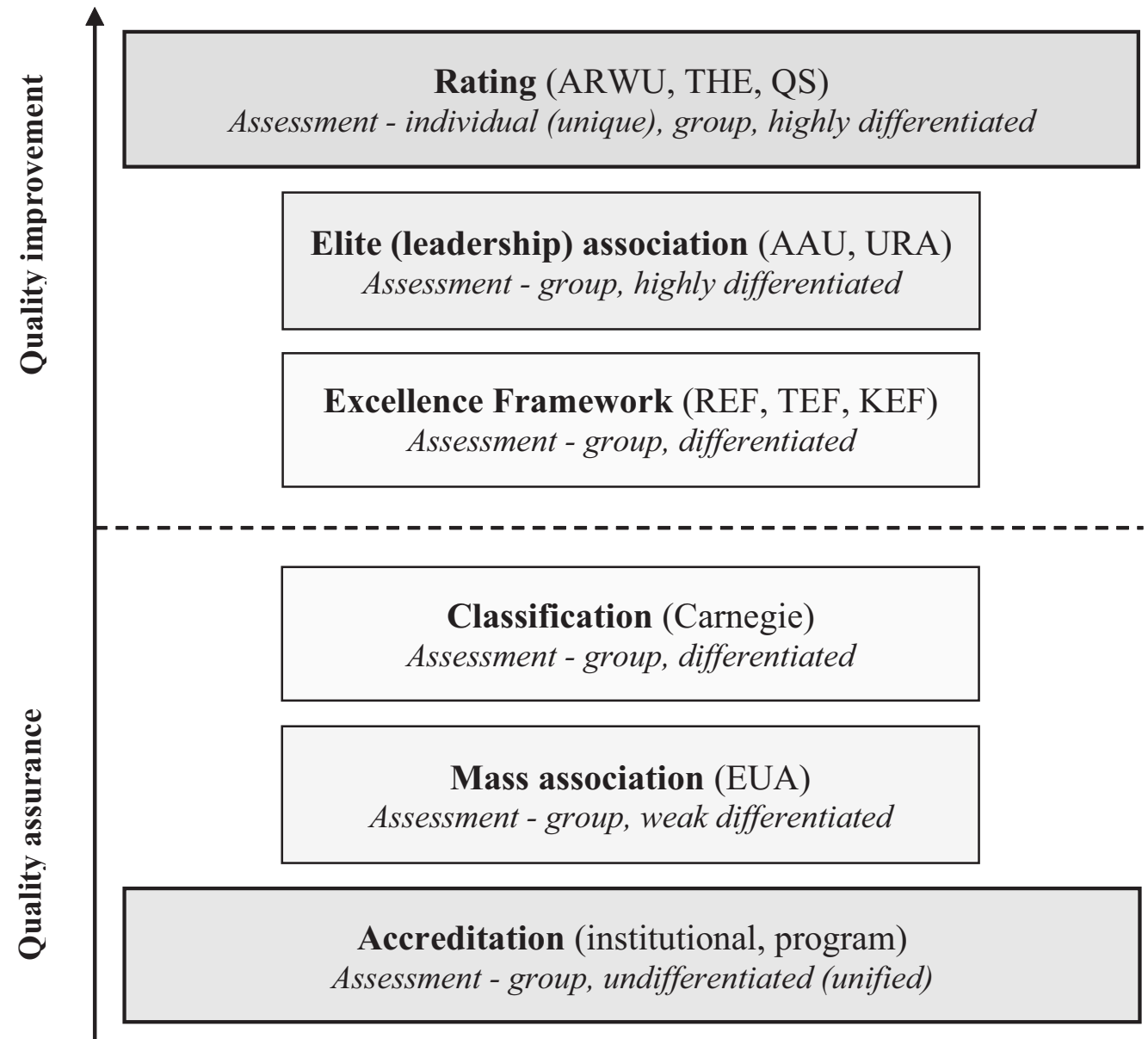

Fig. 2.

Classification of mechanisms for assessing the higher education quality by the ability to identify the quality level

Note: See the abbreviations in the text below.

Source: Designed by authors (Lugovyi \& Talanova (eds.), 2019, 2019a).

In Ukraine, most mechanisms, except for accreditation and mass association, are not formed and are not used. Therefore, it is currently impossible to fully determine the higher education quality profile in the country (Lugovyi, Slyusarenko \& Talanova, 2019; Lugovyi \& Talanova (eds.), 2019, 2019a). 


\section{METHODOLOGY}

For the purposes of this study, the basic category "higher education quality profile" is interpreted as a systemically structured (integrated and differentiated) characteristic of educational quality in the range of values from basic (minimum sufficient) to the highest (most perfect). Quality attributes are considered in two dimensions - institutional (general) and program (sectoral or subject). To diagnose and identify educational quality, it is envisaged to use a system of appropriate mechanisms for assessing the higher education quality, the range of which extends from accreditation (the lowest threshold mechanism) to the rating (the highest precision mechanism).

Also the quality of higher education, HEIs is determined by the degree of their adequacy to the declared mission (Lugovyi, Slyusarenko \& Talanova, 2019).

The study applied, confirmed and developed the methodological position that the university mission determines the place and role of higher education, individual HEIs and their programs and qualifications / degrees in society and economics, is the criterion for their diagnosis and quality identification, status classification, and determines appropriate mechanisms for monitoring and evaluation, motivation higher education quality assurance and enhancement (Lugovyi, Slyusarenko \& Talanova, 2018, 2019; Lugovyi \& Talanova (eds.), 2019, 2019a; Slyusarenko, 2015).

For the purposes of the study, large databases of OECD, NSF, international and domestic rankings, the State Statistics Service of Ukraine, the Information System "Education.UA" (OECD, 2020, 2020a; Table 20 ..., 2020; Academic Ranking ..., 2020; Shanghai Ranking's ..., 2020; THE ..., 2019, 2020; QS .., 2019, 2020; Ranking Web ..., 2020; Derzhstat Ukrainy, 2020; Kilkist zaiav ..., 2020; Konsolidovanyi reitynh ..., 2020; Naibilshyi bal ..., 2020; Naibilshyi bal ..., 2020a; Nikulina, Kshevetskyi \& Tereshchuk, 2019; Reitynhy VNZ, 2020; Reitynh ..., 2020; Reitynh ..., 2020a).

As stated in the previous publication (Lugovyi, Slyusarenko \& Talanova, 2019), this study is part and continuation of a comprehensive methodological research on the university potential development, which is consistently carried out by the authors over the last decade (Lugovyi, Orzhel, Slyusarenko \& Talanova, 2018; Lugovyi, Sliusarenko \& Talanova, 2019, 2019a, 2019b, 2018, 2011; Lugovyi \& Talanova (ed.), 2019, 2019a; Slyusarenko, 2015; Talanova, 2010).

In the paper the terms "HEIs" and "Universities" are used synonymously.

\section{MAIN RESULTS}

Since the top of the ranking pyramid is now dominated by ARWU, this rating in the study is taken as the basis for determining the highest levels of higher education quality. Also due to the fact that according to this rating, the USA has the most powerful higher education in the world, the experience of monitoring and evaluation of higher education quality assurance and enhancement of this country is primarily taken into account. And among the universities, the constant leader in ARWU Harvard University, as well as the second in this ranking Stanford University attracts attention (Academic Ranking ..., 2020; Shanghai Ranking's ..., 2020).

As shown in studies (Lugovyi \& Talanova (ed.), 2019, 2019a), all but the framework mechanisms listed in the classification are developed and functioning in the USA (see Fig. 2). Figure 3 illustrates their action and the role of each in the defined quality profile of Harvard University. 


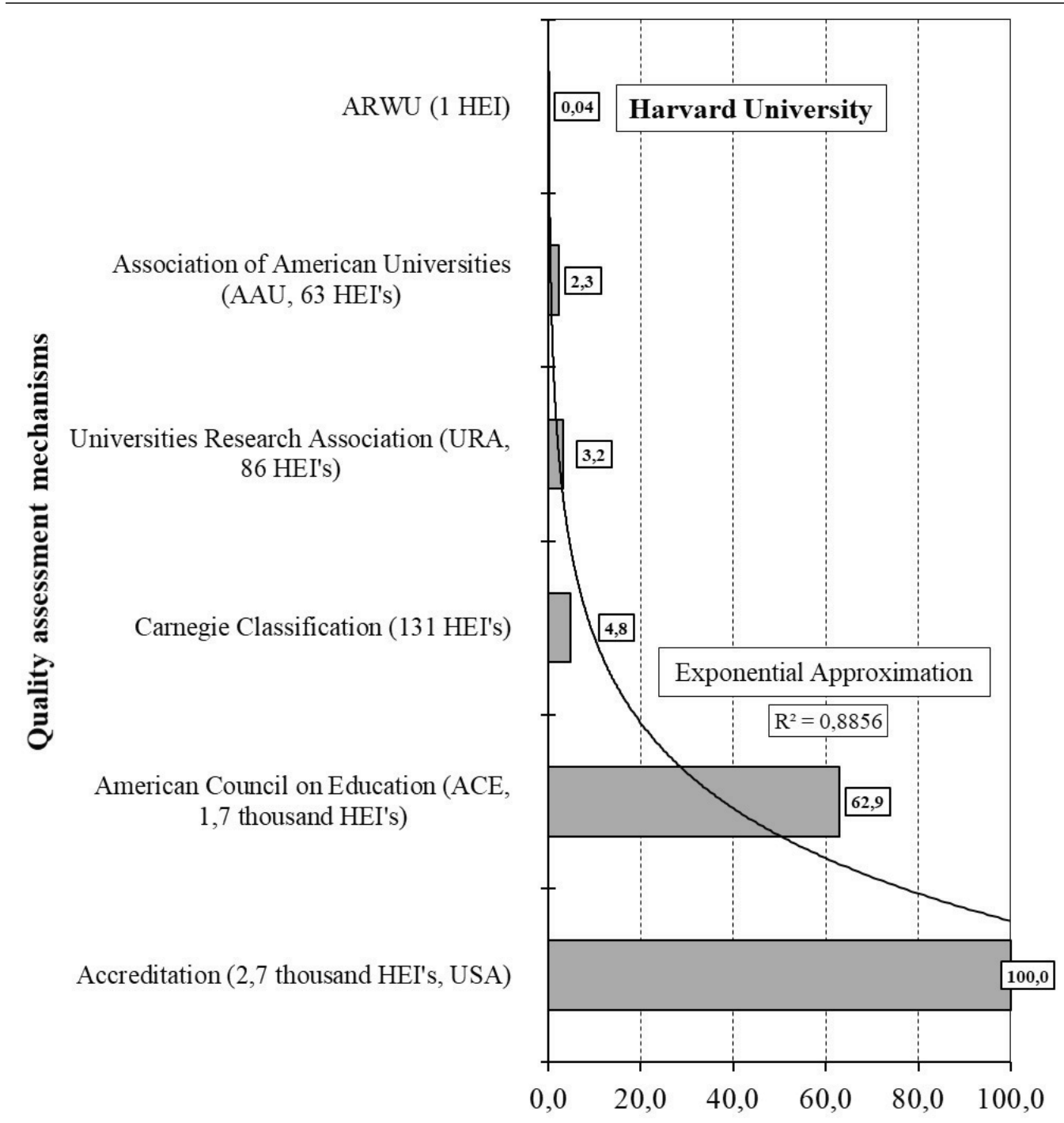

\section{Uncertainty of Harvard University quality assessment as a part of 2,7 thousand 4 -year HEI's of the USA, \%}

Fig. 3.

Identification of Harvard University's quality level by various quality assessment mechanisms

Source: Designed by authors (Lugovyi \& Talanova (eds.), 2019, 2019a).

Figure 3 shows that Harvard University's accreditation does not distinguish it from the 2,700 4-year HEIs awarded bachelor's and higher degrees in the United States. Accreditation for Harvard University is self-evident and formally indicates only that the institution has basic quality characteristics. This is so obvious. Further, Harvard University's affiliation with the American Council on Education does not distinguish it from the 1.7 thousand institutions mentioned above. This is just another indication that the institution has basic quality attributes (Lugovyi \& Talanova (eds.), 2019, 2019a).

Carnegie Classification is a more precise quality assessment mechanism, which narrows the range of institutions with highly competitive qualities to 131 (group R1). Several elite 
university associations raise the bar even higher. According to the Universities Research Association (URA), Harvard University is among the 86 leading American universities, and according to the Association of American Universities (AAU) - among 63. These mechanisms for identifying university quality are group, so they can not personalize institutions by top level of excellence. It is the ratings that remove this limitation. According to ARWU, Harvard University is consistently the first since 2003, when this rating emerged (Carnegie ..., 2018; Universities ..., 2020; Association ..., 2020; Lugovyi \& Talanova (eds.), 2019, 2019a).

Application of the mechanisms specified in Fig. 3, to Stanford University shows that all of them, except ARWU, do not show a significant difference between Harvard and Stanford. Instead, according to ARWU, the general version of Harvard University is significantly ahead of Stanford University, in 2020 by a quartile on a 100-point scale (Academic Ranking ..., 2020).

The appearance in 2017 of the sectoral (for academic subjects) version of ARWU (see Table 1) complements the integrated assessment of the overall version of the rating by differential one (Shanghai Ranking's ..., 2020). This makes it possible to further specify the profile of Harvard, as can be seen in part from Table 1.

Table 1

Comparison of subject rankings of HEIs by ARWU 2017-2020

\begin{tabular}{|c|c|c|c|c|c|c|}
\hline \multirow[b]{2}{*}{$\mathbf{N}$} & \multirow[b]{2}{*}{ Rating parameter } & \multicolumn{5}{|c|}{ Years } \\
\hline & & 2017 & 2018 & 2019 & 2020 & $\begin{array}{l}2020 / \\
2017, \\
\text { times }\end{array}$ \\
\hline 1 & 2 & 3 & 4 & 5 & 6 & 7 \\
\hline 1 & $\begin{array}{l}\text { Methodology including } 5 \\
\text { indicators }\end{array}$ & \multicolumn{5}{|c|}{ No changes } \\
\hline 2 & Number of subjects & 52 & 54 & 54 & 54 & 1,04 \\
\hline 3 & $\begin{array}{l}\text { Number of examined } \\
\text { institutions }\end{array}$ & $\begin{array}{l}>>4 \\
\text { thousand }\end{array}$ & $\begin{array}{l}>4 \\
\text { thousand }\end{array}$ & $\begin{array}{l}>4 \\
\text { thousand }\end{array}$ & $\begin{array}{l}\quad>4 \\
\text { thousand }\end{array}$ & 1,0 \\
\hline 4 & $\begin{array}{l}\text { Total number of positions by } \\
\text { subjects }\end{array}$ & $\begin{array}{l}14,4 \\
\text { thousand }\end{array}$ & $\begin{array}{l}>18,4 \\
\text { thousand }\end{array}$ & $\begin{array}{l}19,2 \\
\text { thousand }\end{array}$ & $\begin{array}{l}19,1 \\
\text { thousand }\end{array}$ & 1,33 \\
\hline 5 & $\begin{array}{l}\text { Number of countries in the } \\
\text { ranking }\end{array}$ & 80 & 83 & 86 & 90 & 1,13 \\
\hline 6 & $\begin{array}{l}\text { Number of institutions in the } \\
\text { ranking }\end{array}$ & $\begin{array}{l}>1,4 \\
\text { thousand }\end{array}$ & $\begin{array}{l}>>1,6 \\
\text { thousand }\end{array}$ & $\begin{array}{l}>>1,7 \\
\text { thousand }\end{array}$ & $\begin{array}{l}\quad>1,8 \\
\text { thousand }\end{array}$ & 1,29 \\
\hline 7 & Number of USA positions & 3857 & 4661 & 4808 & 4826 & 1,25 \\
\hline 8 & Number of Chinese positions & 1652 & 2171 & 2451 & 2647 & 1,60 \\
\hline 9 & Number of UK positions & 1168 & 1487 & 1554 & 1607 & 1,38 \\
\hline 10 & $\begin{array}{l}\text { Number of USA top }\left(1^{\text {th }}\right) \\
\text { positions in subjects }\end{array}$ & 32 & 35 & 35 & 31 & 0,97 \\
\hline 11 & $\begin{array}{l}\text { Number of Chinese top } \\
\text { positions in subjects }\end{array}$ & 8 & 9 & 11 & 11 & 1,38 \\
\hline 12 & $\begin{array}{l}\text { Harvard University (number of } \\
1^{\text {st }} \text { places in subjects) }\end{array}$ & 15 & 17 & 14 & 14 & 0,93 \\
\hline 13 & $\begin{array}{l}\text { Massachusetts Institute of } \\
\text { Technology } \\
\text { (number of } 1^{\text {st }} \text { places in subjects) }\end{array}$ & 5 & 5 & 5 & 6 & 1,2 \\
\hline
\end{tabular}

Source: Compiled by the authors based on: ShanghaiRanking's ..., 2020. 
Table 1 confirms the qualitative superiority of USA universities in general and Harvard University in particular.

Figure 4 shows a detailed quality profile of Harvard University for 54 academic subjects of the sectoral version of ARWU and its dynamics in 2017-2020. In 2017-2019, Harvard was represented in 48 (89\%) academic subjects, of which $14-17$ (26-31\%) in the first positions. In 2020, $47(87 \%)$ and 14 (26\%), respectively. The detailed quality profile of Harvard University generally remains stable (Academic Ranking ..., 2020; Shanghai Ranking's ..., 2020).

\begin{tabular}{|c|c|c|}
\hline$\diamond \quad$ Harvard Univ. 2017 & o & Harvard Univ. 2018 \\
\hline Harvard Univ. 2019 & $\square$ & Harvard Univ. 2020 \\
\hline ....... Polinomial approximation (Harvard Un. 2017) & --- & Polinomial approximation (Harvard Un. 2018) \\
\hline - - - - Polinomial approximation (Harvard Un. 2019) & $\longrightarrow$ & Polinomial approximation (Harvard Un. 2020) \\
\hline
\end{tabular}

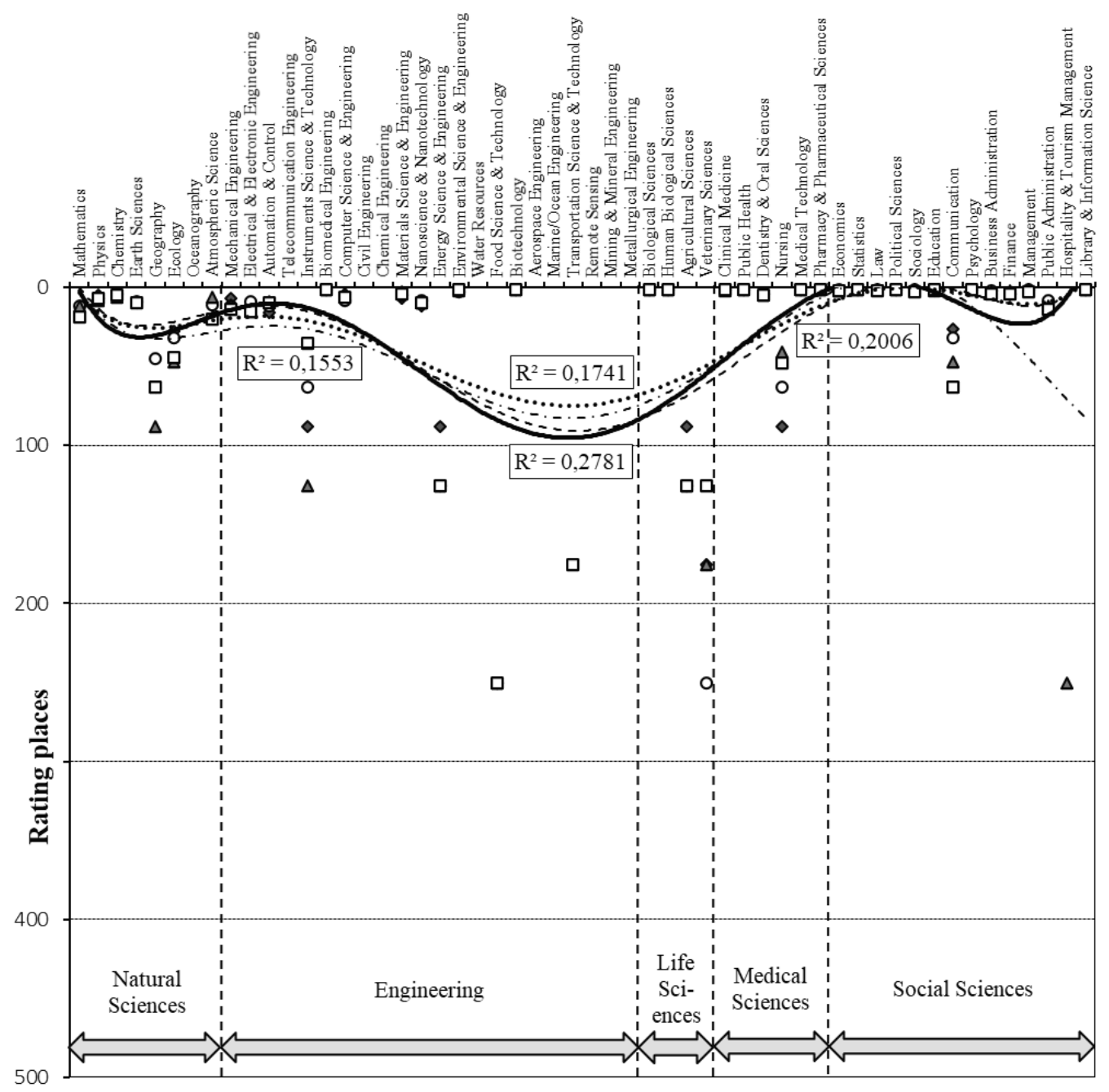

Groups of Academic Sudjects

Fig. 4

Detailed quality profile of Harvard University for 54 academic subjects of the sectoral version of ARWU in 2017-2020.

Source: Compiled by the authors based on: ShanghaiRanking's ..., 2020.

Figure 4 illustrates that Harvard University has a strong position in each group of subject areas - Natures Sciences, Engineering, Life Sciences, Medical Sciences, and Social Sciences. 
Particularly high quality university in Life Sciences (50\% of the first positions), Medical Sciences (67\%), and Social Sciences (36\%). The average rating score within these groups is high: Natures Sciences - 24.0; Engineering - 49.9; Life Sciences - 63.3; Medical Sciences - 9.5, and Social Sciences $-7.7 \%$. It can be argued that Harvard University is particularly advanced in Medical and Social Sciences.

Figure 5 shows the comparison of the detailed quality profiles of Harvard University and Stanford University.

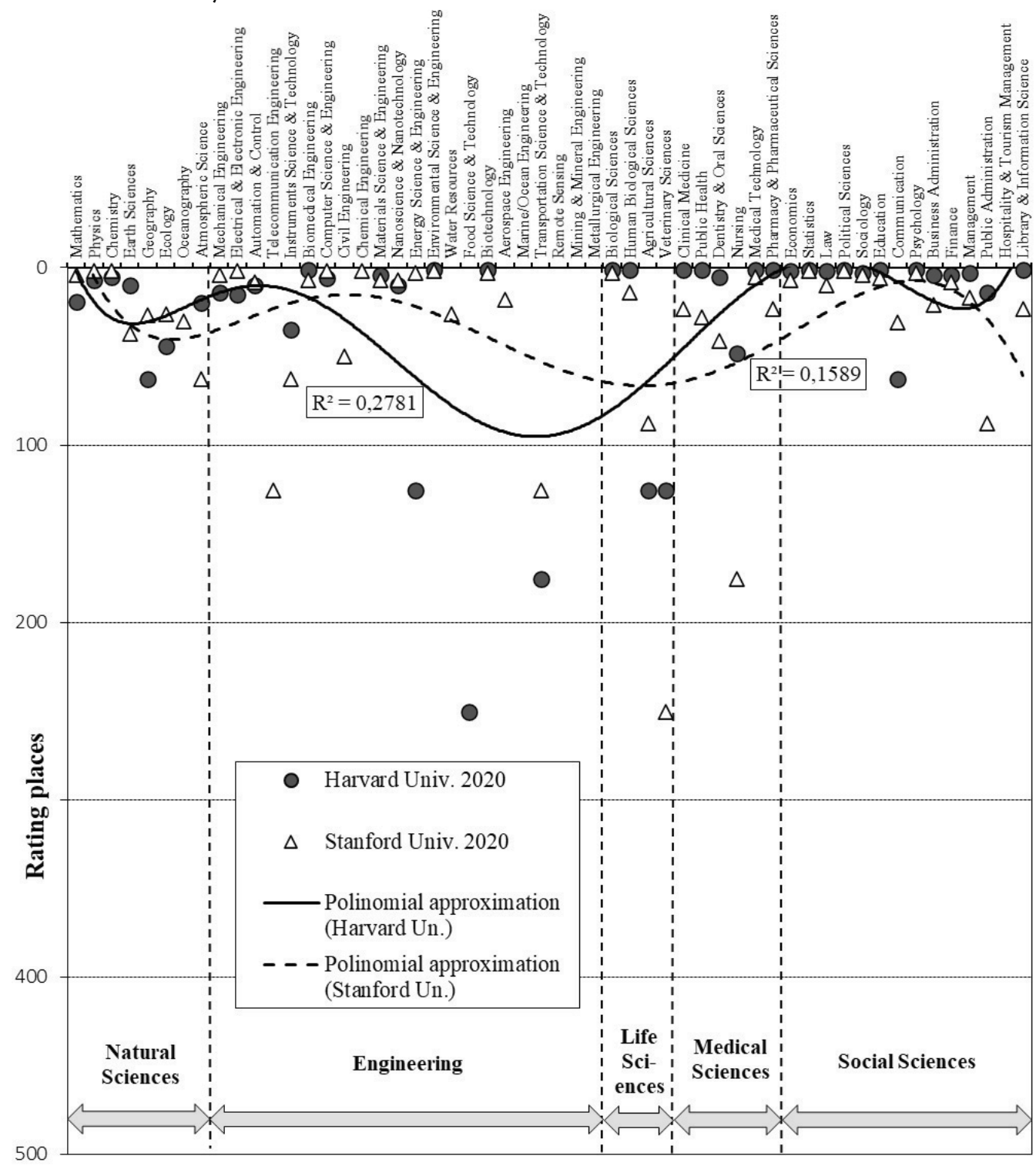

\section{Groups of Academic Sudjects}

Fig. 5.

Comparison of detailed quality profiles of Harvard University and Stanford University according to ARWU 2020

Source: Compiled by the authors based on: ShanghaiRanking's ..., 2020.

Figure 5 illustrates that Harvard University is generally ahead of Stanford University in Medical and Social Sciences, but behind Egineering. At the same time, Stanford University in 2020 does not have any first place among 54 academic subjects of ARWU. 
Critics and opponents of ARWU in Ukraine often argue that this ranking places too much emphasis on the research and innovation achievements of institutions. That is, this rating is not valid for Ukrainian institutions, in which research and development (R\&D) funding is weak, in particular due to the existence of state-run academies of sciences. This position, as unfounded and erroneous, is refuted by world experience.

Figure 6 shows the correlation of the ranking places of the first 30 according to ARWU HEIs of the USA and their rating positions in terms of R\&D funding.

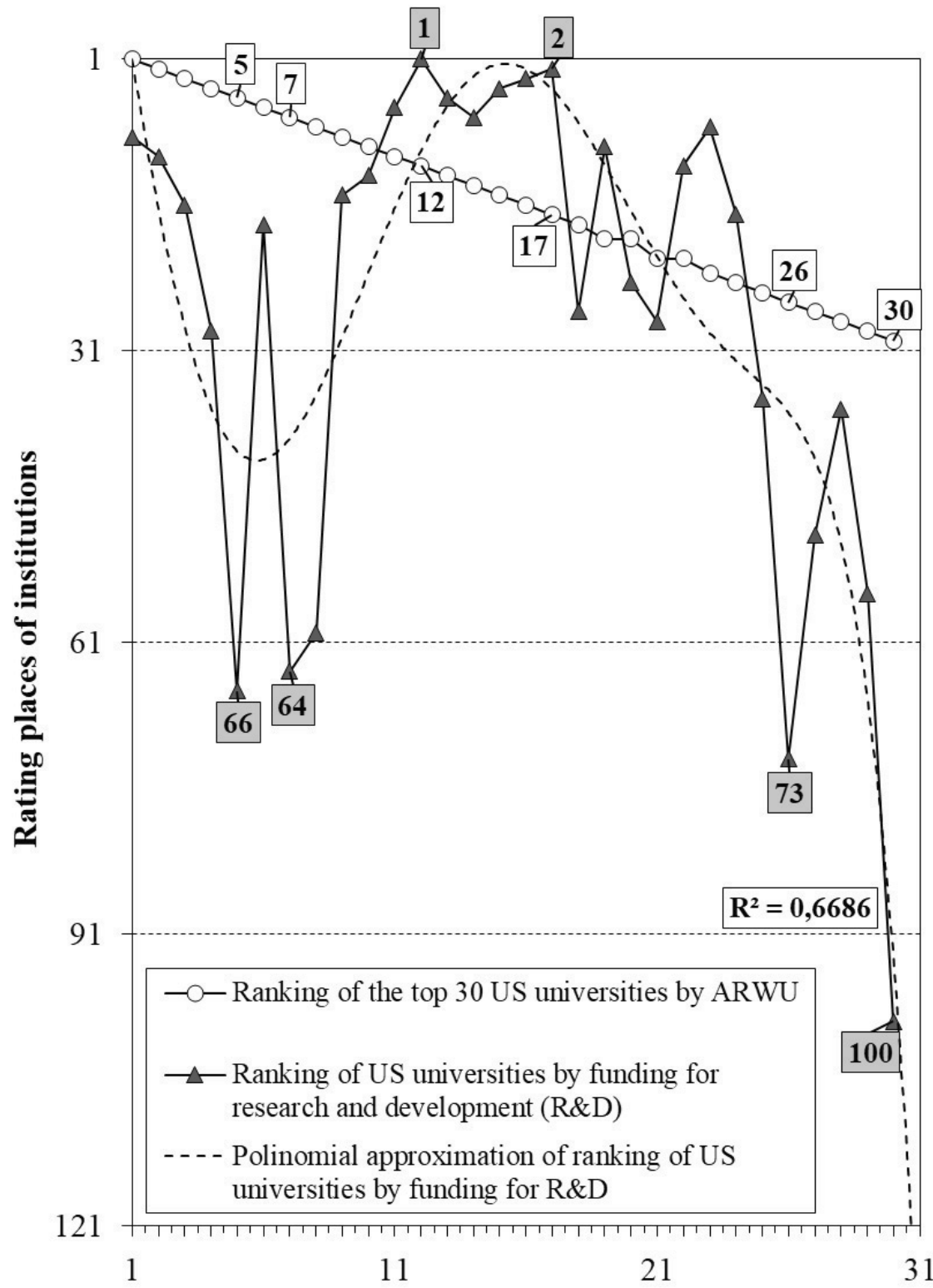

Rating places of institutions by ARWU $2020(\mathrm{~N}=30)$

Fig. 6.

Comparison of the ranking positions of the first top 30 US universities according to the ARWU 2020 rating and the places of these institutions in terms of R\&D funding in 2018.

Source: Compiled by the authors based on: Academic Ranking ..., 2020; Table 20 .., 2020. 
Figure 6 illustrates the lack of a mutually unambiguous correspondence between the rating place according to ARWU and the amount of funding for R\&D of the institution. The calculation of Pearson's correlation coefficient $\left(\mathrm{K}_{\text {pear }}=0.32\right.$ for $\mathrm{K}_{\mathrm{cr}}=0.36$ (Horoneskul (compl.), 2009)) showed no probable correlation. In addition, back in 2015, O. Slyusarenko proved by calculating Spearman's rank-order correlation that the rating achievements of the first 30 institutions according to ARWU (from USA, UK, Switzerland, Japan, and Canada) do not depend on the amount of the annual budget for $\mathrm{R} \& \mathrm{D}\left(\mathrm{K}_{\mathrm{sp}}=0.02\right)$, nor from the share of this budget $\left(\mathrm{K}_{\mathrm{sp}}=0.01\right)$ (Slyusarenko, 2015). This refutes the popular claim in Ukraine that only universities with very strong-funded R\&D have a chance to join ARWU. And since there are few such institutions in the country, Ukrainian higher education is not represented in this ranking. That is, ARWU is not for Ukraine, which needs something simplier.

This does not take into account several key circumstances.

The first one. Throughout the world, R\&D is funded mainly outside universities. For example, in the USA $87 \%$, and in China, as well as in Ukraine, $93 \%$ of funding goes to nonuniversity institutions (Lugovyi, Orzhel, Slyusarenko \& Talanova, 2018; OECD, 2020a).

The second one. The main source of university research and innovation potential is the maximum realization of the scientific and pedagogical function of teachers (faculties) on the principle of "professor and researcher - one person" or "research professor". There are good preconditions for this in Ukraine, as HEIs concentrate more than $70 \%$ of the candidates and doctors of sciences available in the country's economy. However, this is possible in resourceintensive, enlarged universities (Lugovyi, Slyusarenko \& Talanova, 2019a). In particular, in 2018 in the USA out of 2.7 thousand 4-year HEIs awarding bachelor's and higher degrees, only 915 (33.9\%) received R\&D funding of 150 thousand dollars and more (Table 20 ..., 2020; Gibbons, 2020). In Ukraine, as well, less than half of HEIs have research organizations and receive special expenditures for $\mathrm{R} \& \mathrm{D}$, which, importantly, are not the main but ancillary activities of institutions. In addition, specially funded research and innovation departments of universities (research institutes, units, sectors) often remain poorly integrated with educational departments. The reason is that their priority goal is not to modernize the educational process, but to fulfill the tasks of an external customer. Self-financing of R\&D in Ukrainian universities is almost underdeveloped in contrast to the United States, where it reaches 26\%, and, for example, at Harvard University - 30\% (Lugovyi, Slyusarenko \& Talanova, 2019a; Gibbons, 2020).

The third one. In 2017, Taras Shevchenko National University of Kyiv was already included in the group of top 500 ARWU institutions in the subject of "mathematics". That is, ARWU is subjugated. At the same time, the fact that the flagship of Ukrainian higher education did not stay in this ranking means a relative weakening of Ukraine's university potential in the context of increasing global competition (Shanghai Ranking's ..., 2020). The use of other world university rankings THE (subjective by a third) and QS (subjective by half) (Slyusarenko, 2015) does little to determine the top quality of higher education in Ukraine. A total of nine Ukrainian universities are currently in these rankings, which are rated differently, and in general most of them have deteriorated in recent years. It is impossible to detect "Ukrainian Harvard" from them, as it can be seen from Tables 2-4. The Table 2 shows the Ukrainian HEIs present in the THE and QS rankings of the last two years (Lugovyi, Slyusarenko \& Talanova, 2019; THE ..., 2019, 2020; QS ..., 2019, 2020).

Table 2 shows that with the help of two achievable for Ukrainian HEIs ratings THE and QS it is possible to outline only approximately a group of leading domestic institutions. Instead, it is probably impossible to specify their top leadership (first, second, third, etc.) in more detail. For example, according to THE, Lviv Polytechnic National University and Sumy State University are in the first half of the ranking list, and according to QS - V.N. Karazin 
Kharkiv National University. But this is enough to identify the university group for its priority government support to close the global gap, in particular, to join the ARWU. This is relevant, because, for example, for QS 2021 the flagship of domestic higher education Taras Shevchenko National University of Kyiv (601-650 places) is twice inferior to the Belarusian State University (317 th place). According to THE, both of them are in the group of $1000+$ among 1.5 thousand institutions (THE ..., 2019, 2020; QS ..., 2019, 2020).

Sectoral versions of THE and QS are also uninformative (see Tables 3 and 4).

Table 2

\section{Positions Ukrainian Institutions of Higher Education according to the ratings of THE and QS 2020-2021}

\begin{tabular}{|c|c|c|c|c|c|}
\hline \multirow[t]{2}{*}{$\mathbf{N}$} & \multirow[t]{2}{*}{ HEIs } & \multicolumn{2}{|c|}{$\begin{array}{l}\text { THE } \\
\text { years }\end{array}$} & \multicolumn{2}{|c|}{$\begin{array}{c}\text { QS } \\
\text { years }\end{array}$} \\
\hline & & 2020 & 2021 & 2020 & 2021 \\
\hline 1 & 2 & 3 & 4 & 5 & 6 \\
\hline 1 & Lviv Polytechnic National University & $801-1000$ & $501-600$ & $751-800$ & $801-1000$ \\
\hline 2 & Sumy State University & $1001+$ & $501-600$ & $701-750$ & $701-750$ \\
\hline 3 & Kharkiv National University of Radio Electronics & - & $800-1000$ & - & - \\
\hline 4 & Ivan Franko National University of Lviv & $1001+$ & $1001+$ & - & - \\
\hline 5 & $\begin{array}{l}\text { National Technical University Kharkiv Polytechnic } \\
\text { Institute }\end{array}$ & $1001+$ & $1001+$ & $651-700$ & $651-700$ \\
\hline 6 & $\begin{array}{l}\text { National Technical University of Ukraine - Igor } \\
\text { Sikorsky Kyiv Polytechnic Institute }\end{array}$ & - & $1001+$ & $701-750$ & $701-750$ \\
\hline 7 & Taras Shevchenko National University of Kyiv & $1001+$ & $1001+$ & $541-550$ & $601-650$ \\
\hline 8 & V.N. Karazin Kharkiv National University & $1001+$ & $1001+$ & 491 & 477 \\
\hline 9 & Yuriy Fedkovych Chernivtsi National University & - & $1001+$ & - & - \\
\hline \multicolumn{2}{|c|}{ Number of ranked institutions } & 1397 & 1527 & 1002 & 1002 \\
\hline \multicolumn{2}{|c|}{ Number of countries, territories } & 92 & 93 & 82 & 80 \\
\hline
\end{tabular}

Source: Compiled by the authors based on: THE ..., 2019, 2020; QS ..., 2019, 2020.

Table 3

\section{Positions of Ukrainian universities according to the rating of THE 2020 sectoral (subject) version}

\begin{tabular}{|c|c|c|c|c|c|c|c|}
\hline $\mathbf{N}$ & Subjects & $\begin{array}{c}\text { Lviv } \\
\text { Polytechnic } \\
\text { National } \\
\text { University }\end{array}$ & $\begin{array}{c}\text { Taras } \\
\text { Shevchenko } \\
\text { National } \\
\text { University } \\
\text { of Kyiv }\end{array}$ & $\begin{array}{c}\text { V.N. } \\
\text { Karazin } \\
\text { Kharkiv } \\
\text { National } \\
\text { University }\end{array}$ & $\begin{array}{l}\text { National } \\
\text { Technical } \\
\text { University } \\
\text { Kharkiv } \\
\text { Polytechnic } \\
\text { Institute }\end{array}$ & $\begin{array}{c}\text { Ivan } \\
\text { Franko } \\
\text { National } \\
\text { University } \\
\text { of Lviv }\end{array}$ & $\begin{array}{c}\text { Sumy } \\
\text { State } \\
\text { University }\end{array}$ \\
\hline 1 & 2 & 3 & 4 & 5 & 6 & 7 & 8 \\
\hline \multicolumn{2}{|c|}{$\begin{array}{l}\text { I. Clinical, pre-clinical } \\
\text { and health }\end{array}$} & & & & & & \\
\hline 1 & Medicine \& dentistry & & & & & & \\
\hline 2 & Other health & & & & & & \\
\hline
\end{tabular}




\begin{tabular}{|c|c|c|c|c|c|c|c|}
\hline \multicolumn{2}{|c|}{ II. Life sciences } & & \multirow[b]{2}{*}{$601+$} & & & & \\
\hline 1 & Biological sciences & & & & & & \\
\hline 2 & Sport science & & & & & & \\
\hline 3 & Veterinary science & & & & & & \\
\hline 4 & $\begin{array}{l}\text { Agriculture \& } \\
\text { forestry }\end{array}$ & & $601+$ & & & & \\
\hline \multicolumn{2}{|c|}{ III. Physical sciences } & & & & & & \\
\hline 1 & Physics \& astronomy & $601-800$ & $801+$ & $801+$ & $801+$ & $801+$ & \\
\hline 2 & Chemistry & & $801+$ & $801+$ & & $801+$ & \\
\hline 3 & $\begin{array}{l}\text { Geology, } \\
\text { environmental, earth } \\
\text { \& marine sciences }\end{array}$ & $601-800$ & $801+$ & $801+$ & $801+$ & $801+$ & \\
\hline 4 & $\begin{array}{l}\text { Mathematics \& } \\
\text { statistics }\end{array}$ & $601-800$ & $801+$ & $801+$ & & $801+$ & \\
\hline \multicolumn{2}{|c|}{ IV. Psychology } & & & & & & \\
\hline \multicolumn{2}{|c|}{$\begin{array}{l}\text { V. Business and } \\
\text { economics }\end{array}$} & & & & & & \\
\hline 1 & $\begin{array}{l}\text { Economics \& } \\
\text { econometrics }\end{array}$ & $501+$ & & & & & \\
\hline 2 & $\begin{array}{l}\text { Business \& } \\
\text { management }\end{array}$ & $501+$ & & & & & \\
\hline 3 & $\begin{array}{l}\text { Accounting \& } \\
\text { finance }\end{array}$ & $501+$ & & & & & \\
\hline \multicolumn{2}{|c|}{ VI. Education } & & & & & & \\
\hline \multicolumn{2}{|c|}{ VII. Law } & & & & & & \\
\hline \multicolumn{2}{|c|}{ VIII. Social sciences } & & & & & & \\
\hline 1 & Geography & & & & & & \\
\hline 2 & Sociology & & & & & & \\
\hline 3 & $\begin{array}{l}\text { Politics \& } \\
\text { international studies } \\
\text { (incl. development } \\
\text { studies) }\end{array}$ & & & & & & \\
\hline 4 & $\begin{array}{l}\text { Communication \& } \\
\text { media studies }\end{array}$ & & & & & & \\
\hline \multicolumn{2}{|c|}{$\begin{array}{l}\text { IX. Engineering and } \\
\text { technology }\end{array}$} & & & & & & \\
\hline 1 & General engineering & $601-800$ & & & $801+$ & & $801+$ \\
\hline 2 & Civil engineering & $601-800$ & & & & & \\
\hline 3 & $\begin{array}{l}\text { Mechanical } \\
\text { \& aerospace } \\
\text { engineering }\end{array}$ & $601-800$ & & & & & $801+$ \\
\hline 4 & $\begin{array}{l}\text { Electrical \& } \\
\text { electronic } \\
\text { engineering }\end{array}$ & $601-800$ & $801+$ & $801+$ & $801+$ & & $801+$ \\
\hline 5 & $\begin{array}{l}\text { Chemical } \\
\text { engineering }\end{array}$ & $601-800$ & & & $801+$ & & \\
\hline \multicolumn{2}{|c|}{ X. Computer science } & $251-300$ & $601+$ & & & & \\
\hline
\end{tabular}




\begin{tabular}{|c|l|l|l|l|l|l|l|}
\hline \multicolumn{2}{|l|}{ XI. Arts and humanities } & & & & & & \\
\hline 1 & $\begin{array}{l}\text { Languages, literature } \\
\text { \& linguistics }\end{array}$ & & & & & & \\
\hline 2 & $\begin{array}{l}\text { History, philosophy } \\
8 \text { theology }\end{array}$ & & & & & & \\
\hline 3 & $\begin{array}{l}\text { Art, performing arts } \\
\text { \& design }\end{array}$ & & & & & & \\
\hline 4 & Archaeology & & & & & & \\
\hline 5 & Architecture & & & & & & \\
\hline
\end{tabular}

Source: Compiled by the authors based on: THE ..., 2020.

From the Table 3 it is easy to see that the subject version contains only institutions that are in the general version of the rating. This indicates that institutions with high achievements in certain subject areas are excluded from consideration if they are not included in the rating of the general version. This fundamentally, but for the worse, distinguishes the sectoral version of THE from a similar version of ARWU (see Table 1). In particular, it is somewhat doubtful that Taras Shevchenko National University of Kyiv has the best achievements in Ukraine in Agriculture \& Forestry, and Lviv Polytechnic National University in the field of Business and Economics. This is a drawback in the sectoral version of QS.

Table 4

\section{Positions of Ukrainian universities according to the QS 2020 rating of the sectoral (subject) version}

\begin{tabular}{|c|c|c|c|c|c|c|c|}
\hline $\mathrm{N}$ & $\begin{array}{c}\text { HEIs/ } \\
\text { Subjects }\end{array}$ & $\begin{array}{c}\text { V.N. } \\
\text { Karazin } \\
\text { Kharkiv } \\
\text { National } \\
\text { University }\end{array}$ & $\begin{array}{c}\text { Taras } \\
\text { Shevchenko } \\
\text { National } \\
\text { University } \\
\text { of Kyiv }\end{array}$ & $\begin{array}{l}\text { National } \\
\text { Technical } \\
\text { University } \\
\text { Kharkiv } \\
\text { Polytechnic } \\
\text { Institute }\end{array}$ & $\begin{array}{c}\text { National } \\
\text { Technical } \\
\text { University } \\
\text { of Ukraine } \\
\text { "Igor } \\
\text { Sikorsky Kyiv } \\
\text { Polytechnic } \\
\text { Institute" }\end{array}$ & \begin{tabular}{|} 
Sumy \\
State \\
University
\end{tabular} & $\begin{array}{c}\text { Lviv } \\
\text { Polytechnic } \\
\text { National } \\
\text { University }\end{array}$ \\
\hline 1 & 2 & 3 & 4 & 5 & 6 & 7 & 8 \\
\hline 1 & Chemistry & & $501-550$ & & & & \\
\hline 2 & $\begin{array}{l}\text { Electrical \& } \\
\text { electronic } \\
\text { engineering }\end{array}$ & & & & $451-500$ & & \\
\hline 3 & Mathematics & & $401-450$ & & & & \\
\hline 4 & $\begin{array}{l}\text { Mechanical, } \\
\text { aeronautical \& } \\
\text { manufacturing }\end{array}$ & & & & $451-500$ & & \\
\hline 5 & Modern languages & & $151-200$ & & & & \\
\hline 6 & $\begin{array}{l}\text { Physics \& } \\
\text { astronomy }\end{array}$ & & $401-500$ & & & & \\
\hline
\end{tabular}

Source: Compiled by the authors based on: QS ..., 2020. 
Table 4 illustrates that only two Ukrainian institutions out of six in QS that occupy ranking positions in six subject areas. The sectoral quality profile of Ukrainian universities looks inadequate.

Addressing Ukrainian ratings, which are too proactive in the information space, due to their subjectivity, lack of validity and low probability, further confuses the situation. For example, according to the rating of "Top-200 Ukraine" of the National Technical University of Ukraine "Igor Sikorsky Kyiv Polytechnic Institute" in most cases ranks first, although according to the ratings of THE and QS it has a rather mediocre position (Lugovyi, Slyusarenko \& Talanova, 2019; Lugovyi \& Talanova (eds.), 2019, 2019a; THE ..., 2019, 2020; QS ..., 2019, 2020; Reitynh ..., 2020a).

As only nine (3.2\%) Ukrainian universities are present in the THE and QS international rankings, it is as important to create a national ranking of HEIs of general and sectoral versions, as substantiated in the author's publications and reviews of domestic higher education World Bank. This will make it possible to differentiate most of the 281 HEIs according to the level of achievement. The focus should be on the most objective, clear and transparent ARWU rating methodology. Among the advantages of this rating there is minimum number of criteria / indicators, mission-focused and subject-dependent (Lugovyi \& Talanova (eds.), 2019, 2019a; THE ..., 2019, 2020; QS ..., 2019, 2020; Academic Ranking ..., 2020; Shanghai Ranking's ..., 2020; Derzhstat ..., 2020).

In addition, in order to form a quality profile of Ukrainian higher education, it is necessary to develop, in addition to rating, other mechanisms for determining, monitoring and evaluating educational quality. Among them is the creation, for example, of the Association of American Universities, an elite Association of Ukrainian Universities with 20-30 of the best HEIs, which includes and excludes the best institutions depending on their achievements (Lugovyi \& Talanova (eds.), 2019, 2019a; Association ..., 2020).

Also by the UK example, the frameworks for excellence in research, teaching, knowledge exchange at universities (REF, TEF, KEF) can be introduced (Lugovyi \& Talanova (eds.), 2019, 2019a).

Using the experience of the USA Carnegie Classification, the classification of Ukrainian accredited universities should be introduced according to the level and scale of educational provision (educational, educational-scientific, scientific programs). That is, HEIs can be divided into global, regional, national, subnational and local. After all, not all institutions should be required to be globally competitive. For example, in 2018, abnormally many of the 282 HEIs had postgraduate (aspiranture) studies (221, or 78.4\%) and postdoctoral studies (174, or 61.7\%) (Lugovyi \& Talanova (eds.), 2019, 2019a; Carnegie ..., 2018; Derzhstat ..., 2020).

The lack of the system of quality assessment mechanisms in Ukraine does not allow creating a profile of higher education, both in general institutional and specifically sectoral (for academic subjects). Therefore, the annual action plans for the implementation of the Strategy for the Development of Higher Education in Ukraine for 2021-2031, which is being developed, will not have a real basis (Lugovyi, 2020; Prezydent ..., 2020).

\section{CONLUSIONS}

From the above, the following conclusions follow.

1. Ukrainian higher education in 1990-2019 grew quantitatively and chaotically with a simultaneous loss of competitive quality. As a result, the country has a fragmented and dispersed, over-duplicated, profile-inadequate, institutionally and resource-weak, researchpoor, and ultimately mission-insufficient network of higher education institutions. Therefore, according to ARWU, Ukraine is identified as a white spot in Europe, which does not get into 
the list of 60 countries in general version and 90 countries in the sectoral (subject) version of this rating.

2. This situation is largely due to the lack of a holistic system of mechanisms for monitoring and evaluation, ensuring and improving the quality of higher education. In contrast to the best practices of progressive countries, Ukraine does not have developed classification, framework, association and rating mechanisms. Accreditation mechanisms do not cope and in principle can not cope with the systematic diagnostics and effective motivation of the quality of higher education in the entire range of quality - from the minimum threshold to the breakthrough of the most perfect. This leads to the lack of a credible quality profile of domestic higher education and, as a consequence, difficulties in determining the strategic and operational goals of development of this educational sphere.

3. The basic category "higher education quality profile" should be interpreted as a systemically structured (integrated and differentiated) characteristic of educational quality in the range of values from basic (minimum sufficient) to the highest (most perfect). At the same time, quality attributes should be considered in two dimensions - institutional (general) and program (sectoral or subject). Diagnostics and identification of educational quality should be carried out using a set of appropriate mechanisms for assessing the quality of higher education, the range of which extends from accreditation (the lowest threshold mechanism) to the rating (the highest precision mechanism).

4. In order to form a reliable reference point and justify the way out of the crisis, it is important to know in detail the best world achievements, first of all the leading countries of university education of the USA, to make comparisons between Ukraine and the USA. In particular, to illustrate the definition of the profile of university quality, you can use the example of Harvard University.

5. Forming a set of quality assessment mechanisms developed and tested by the best international practice is among the urgent tasks of modernization of Ukrainian higher education. This applies to the introduction of the national ranking of higher education institutions of general and sectoral versions on the principles of ARWU methodology, the creation of a leadership Association of Ukrainian Universities following the example of the Association of American Universities, the development of classifications of institutions by level and scale of educational provision (educational, educational-scientific, scientific programs) like Carnegie Classification, and construction on this basis, considering accreditation, credible higher education quality profile in Ukraine.

\section{REFERENCES}

Academic Ranking of World Universities. (2020). Retrieved 2020 from: http://www. shanghairanking.com/index.html

Association of American Universities. (2020). Retrieved 2020 from: https://www.aau.edu/

Carnegie Classification of Academic Institutions. (2018). Retrieved 2020 from: https:// www.nsf.gov/statistics/2018/nsb20181/assets/561/carnegie-classification-of-academicinstitutions.pdf

Derzhstat Ukrainy. (2020). Vyshcha osvita v Ukraini u 2019 rotsi [State Statistics Service of Ukraine. Higher education in Ukraine in 2019]. Retrieved 2020 from: http://www. ukrstat.gov.ua/

Gibbons, Michael T. (2020). Higher Education R\&D Funding from All Sources Increased for the Third Straight Year in FY 2018. Retrieved 2020 from: https://www.nsf.gov/statistics/2020/ nsf20302/nsf20302.pdf

Horoneskul, M. (compl.) (2009). Tablytsi funktsii ta krytychnykh tochok rozpodiliv (Rozdily: 
Teoriia ymovirnostei, Matematychna statystyka, Matematychni metody v psykholohii) [Tables of functions and critical distribution points. Sections: Probability Theory, Mathematical statistics, Mathematical methods in psychology]. Kharkiv: UTsZU. Retrieved 2019 from: http://repositsc.nuczu.edu.ua/bitstream/123456789/1530/1/Tablici. pdf

IREG Observatory on Academic Ranking and Excellence. (2020). Retrieved 2020 from: http:// ireg-observatory.org/en/

Kano model. (2020). Retrieved 2020 from Wikipedia: https://en.wikipedia.org/wiki/Kano_ model

Kilkist zaiav vstupnykiv za rehionamy. (2020) [Number of applications by entrants by region]. Vstup. OSVITA.UA. Retrieved 2020 from: https://osvita.ua

Kompas. Rejting ukrainskih vysshih uchebnyh zavedenij po stepeni udovletvorennosti obrazovaniem (2019) [Compass. Rating of Ukrainian higher education institutions by degree of satisfaction with education]. Retrieved 2019 from http://www.yourcompass. org/

Konsolidovanyi reitynh vyshiv Ukrainy 2020 roku. (2020) [The consolidated rating of Ukrainian universities in 2020]. Retrieved 2020 from: https://osvita.ua/vnz/rating/51741/ Lugovyi, V. I. (2020). Problema osvitnoi yakosti v stratehii rozvytku vyshchoi osvity v Ukraini [The problem of educational quality in the strategy for the development of higher education in Ukraine]. The Herald of the National Academy of Educational Sciences of Ukraine, 2(2). https://doi.org/10.37472/2707-305X-2020-2-2-11-1

Lugovyi, V., Orzhel, O., Slyusarenko, O. \& Talanova, Zh. (2018). Education and research duality - the determining characteristic of higher education. Education: Modern Discuorses, 1, 71-88. https://doi.org/10.32405/2617-3107-2018-1-8

Lugovyi, V. I., Slyusarenko, O. M. \& Talanova, Zh. V. (2011). Vikoristannya mizhnarodnih rejtingiv vishih navchalnih zakladiv dlya identifikaciyi najvishogo universitetskogo potencialu [Use of international ratings of higher education institutions to identify the highest university potential]. Visha osvita Ukrayini, 3 (dodatok 2), tom I (26). Tematichnij vipusk "Visha osvita Ukrayini u konteksti integraciyi do yevropejskogo osvitnogo prostoru”, 296-308

Lugovyi, V., Slyusarenko, O. \& Talanova, Zh. (2018). Vid akredytatsii do reitynhu (funktsionuvannia VS rozvytok) [From accreditation to rating (functioning VS development)]. Mizhnarodnyi naukovyi zhurnal "Universytety i liderstvo", 2(6), 3-20. Retrieved 2020 from: https://ul-journal.org/index.php/journal/article/view/77/73

Lugovyi, V., Slyusarenko, O. \& Talanova, Zh. (2019). University rating \& development: challenges and opportunities for Ukraine. Education: Modern Discourses, 2, 60-77. https:// doi.org/10.32405/2617-3107-2019-1-8

Lugovyi, V., Slyusarenko, O. \& Talanova, Zh. (2019a). Realizatsiia doslidnytsko-innovatsiinoho potentsialu universytetiv yak nevidiemnoho skladnyka yikh diialnosti [Realization of the research and innovation potential of universities as an integral part of their activities]. Nauka ta naukoznavstvo: mizhnarodnyi naukovyi zhurnal, 3 (105), 26-45

Lugovyi, V., Slyusarenko, O. \& Talanova, Zh. (2019b). Suchasnist i nadsuchasnist - kryterii yakosti vyshchoi osvity [Contemporality \& Supercontemporality - Criteria of Quality of Higher Education]. Mizhnarodnyi naukovyi zhurnal "Universytety i liderstvo", 1(7), 3-25. Retrieved 2019 from: https://ul-journal.org/index.php/journal/article/view/84/80

Lugovyi, V. (ed.), Talanova, Zh. (ed), Vorobiova, O., Debych M., ... \& Tryma K. (2019). Analiz providnoho vitchyznianoho ta zarubizhnoho dosvidu shchodo otsiniuvannia yakosti vyshchoi osvity $v$ umovakh yevrointehratsii: analitychni materialy (chastyna II) (preprynt) [Analysis of the leading domestic and foreign experience in assessing the quality of 
higher education in the context of European integration: analytical materials (part II) (preprint)]. Kyiv: In-t vyshchoi osvity NAPN Ukrainy. Retrieved 2020 from: https://ihed. org.ua/wp-content/uploads/2020/04/Analiz_ocinki_VO_v_umovah_internac_ch2_ analit_IVO-2019-150p_avtors-kolektiv.pdf

Lugovyi, V. (ed.), Talanova, Zh. (ed), Vorobiova, O., Debych M., ... \& Tryma K. (2019a). Otsiniuvannia yakosti vyshchoi osvity $\mathrm{v}$ umovakh yevrointehratsii: metodychni rekomendatsii [Assessing the quality of higher education in the context of European integration: guidelines]. Kyiv: In-t vyshchoi osvity NAPN Ukrainy. Retrieved 2020 from: https://ihed.org.ua/wp-content/uploads/2020/09/ocinka_yakosti_VO_v_umovah_ evrointegrac_analit_IVO-2019-125p_avtors-kolektiv.pdf

Naibilshyi bal ZNO na biudzhet. (2020). [The highest score of the external evaluation on the budget]. Vstup.OSVITA.UA. Retrieved 2020 from: https:/osvita.ua/vnz/rating/vstuposvita/59046/

Naibilshyi bal ZNO na kontrakt. (2020a). [The highest external evaluation score on contract]. Vstup.OSVITA.UA. Retrieved 2020 from: http://osvita.ua/vnz/rating/vstup-osvita/59045/

Nikulina O., Kshevetskyi V. \& Tereshchuk V. (2019). Vykonannia kryteriiv nadannia ta pidtverdzhennia statusu natsionalnoho zakladu vyshchoi osvity: Analitychnyi zvit [Meeting the criteria for granting and confirming the status of a national higher education institution: analytical report]. Kyiv : Natsionalne ahentstvo iz zabezpechennia yakosti vyshchoi osvity. Retrieved 2019 from: http://www.euroosvita.net/prog/data/attach/6214/ analitichnii_zvit.pdf

OECD. (2009). Higher Education to 2030, Volume 2: Globalisation, Executive Summary, OESD Publishing, Paris. Retrieved 2020 from: http://www.oecd.org/education/ceri/44101074. pdf

OECD. (2020). Education at a Glance 2020: OECD Indicators, OECD Publishing, Paris. Retrieved 2020 from: https://read.oecd-ilibrary.org/education/education-at-a-glance2020_69096873-en\#page1

OECD. (2020a). Main Science and Technology Indicators. Retrieved 2020 from: https://stats. oecd.org/viewhtml.aspx?datasetcode=MSTI_PUB\&lang=en

Prezydent Ukrainy. (2020, 3 chervnia). Pro vdoskonalennia vyshchoi osvity v Ukraini [On the improvement of higher education in Ukraine]. Retrieved 2020 from: https://www. president.gov.ua/documents/2102020-34045

Pro zatverdzhennia pereliku svitovykh reitynhiv universytetiv dlia vyznachennia osoblyvoi katehorii inozemtsiv ta osib bez hromadianstva, yaki pretenduiut na pratsevlashtuvannia v Ukraini. Rozporiadzhennia Kabinetu Ministriv Ukrainy vid 14 bereznia 2018 r. № 154-r. (2018). [On approval of the list of world rankings of universities to determine the special category of foreigners and stateless persons applying for employment in Ukraine. Ordinance of the Cabinet of Ministers of Ukraine]. Retrieved 2019 from: http://zakon2. rada.gov.ua/laws/show/154-2018-\%D1\%80

Pro zatverdzhennia Polozhennia pro natsionalnu systemu reitynhovoho otsiniuvannia diialnosti vyshchykh navchalnykh zakladiv. Nakaz Ministerstva osvity i nauky, molodi ta sportu Ukrainy vid 20 hrudnia 2011 r. № 1475. (2011). [On approval of the Regulation on the national rating system of higher education institutions. Order of the Ministry of Education and Science, Youth and Sports of Ukraine]. Retrieved 2019 from https://zakon. rada.gov.ua/laws/show/z0018-12

QS World University Rankings 2020. (2019). Retrieved 2020 from: https://www.topuniversities. com/university-rankings/world-university-rankings/2020

QS World University Rankings 2021. (2020). Retrieved 2020 from: https://www.topuniversities. com/university-rankings/world-university-rankings/2021 
Ranking Web of Universities. Retrieved 2020 from: http://www.webometrics.info/en

Rankings: A Challenge to Higher Education? (2019). Retrieved 2020 from: http://iregobservatory.org/en/ireg-2019

Reitynhy VNZ. (2020). [HEIs' rankings]. Retrieved 2020 from: https://osvita.ua/vnz/rating/

Reitynh universytetiv za pokaznykamy Scopus 2020 roku. (2020). [Scopus University Rankings 2020]. Retrieved 2020 from: http://osvita.ua/vnz/rating/72780/

Reitynh universytetiv “TOP-200 Ukraina” 2020 roku. (2020a). [The rating of TOP-200 Ukraine universities in 2020]. Retrieved 2020 from: http://osvita.ua/vnz/rating/74898/

Review of the Education Sector in Ukraine. Moving towards Effectiveness, Equity and Efficiency (RESUME3). Overview. World Bank Group. (2019). Retrieved 2020 from: http://documents.worldbank.org/curated/en/360951568662377063/pdf/Overview.pdf

Shanghai Ranking's Global Ranking of Academic Subjects 2020 Press Release. Retrieved 2020 from: http://www.shanghairanking.com/ShanghaiRankings-Global-Ranking-ofAcademic-Subjects-2020-Press-Release.html

Slyusarenko, O. M. (2015). Rozvytok naivyshchoho universytetskoho potentsialu v umovakh hlobalizatsii: monohrafiia [Development of the highest university potential in the conditions of globalization: monograph]. Kyiv: Priorytety.

Table 20. Higher education R\&D expenditures ranked by FY 2018 R\&D expenditures: FYs 2009-18. (2020). Retrieved 2020 from: https://ncsesdata.nsf.gov/herd/2018/html/herd18dt-tab020.html

Talanova, Zh. V. (2010). Doktorska pidhotovka u sviti ta Ukraini: monohrafiia [Doctoral training in the world and Ukraine: monograph]. Kyiv: Milenium

The Complete Guide to the Kano Model. (2019). Retrieved 2020 from: https://foldingburritos. com/kano-model/

THE World University Rankings (2019). Retrieved 2020 from: https://www. timeshighereducation.com/world-university-rankings/2020/world-ranking\#!/page/0/ length/25/sort_by/rank/sort_order/asc/cols/stats

THE World University Rankings. (2020). Retrieved 2020 from: https://www. timeshighereducation.com/world-university-rankings/2021/world-ranking\#!/page/0/ length/25/sort_by/rank/sort_order/asc/cols/stats

University Quality Indicators: A Critical Assessment: Study. (2015). Retrieved from: http://www.europarl.europa.eu/RegData/etudes/STUD/2015/563377/IPOL_ STU\%282015\%29563377_EN.pdf

Universities Research Association. (2020). Retrieved 2020 from: https://en.wikipedia.org/wiki/ Universities_Research_Association

Vymohy spozhyvacha zalezhno vid profiliu yakosti. Model profiliu yakosti (za N. Kano), yoho skladovi. (2018). [Consumer requirements depending on the quality profile. Quality profile model (according to N. Kano), its components]. Retrieved 2020 from: https:// studfile.net/preview/7382023/page:5/

What is Quality Profile? (2020). Retrieved 2020 from: https://www.hse.ie/eng/about/who/ qid/measurementquality/measurementimprovement/what-is-a-quality-profile-. html\#: :text=The\%20Quality\%20Profile\%20is\%20timely,your\%20service\%20in\%20 the $\% 20$ past.\&text=It $\% 20$ is $\% 20$ an $\% 20$ honest $\% 20$ appraisal $\% 20$ of $\% 20$ the $\% 20$ quality $\%$ 20 of $\% 20$ care $\% 20$ provided 